\title{
Morálne naratívy v dejinách. Úvod k diskusii
}

\author{
Moral narratives through history. Introduction to the discussion
}

DOI: 10.31577/EtnoRozpra.2021.28.2.04

\section{Michal Uhrin}

\section{Acknowledgement}

Vydanie príspevku bolo podporené grantom VEGA č. 1/0194/20 Morálne naratívy o náboženských a etnických skupinách vo vyučovaní vybraných predmetov na základných školách.

\section{Kontakt / Contact}

Mgr. Michal Uhrin, PhD., Filozofická fakulta Univerzity Komenského v Bratislave, Gondova 2, 81102 Bratislava, Slovenská republika, e-mail: michal.uhrin@uniba.sk

ORCID (D) https://orcid.org/0000-0002-8062-5785

\section{Ako citovat' / How to cite}

Uhrin, M. (2021). Morálne naratívy v dejinách. Úvod k diskusii. Etnologické rozpravy, 28(2), 54-57. https://doi.org/10.31577/EtnoRozpra.2021.28.2.04

Etnicita, nielen $v$ kontexte morálnych naratívov, predstavuje jednu z nosných tém ako etnológie, tak spoločenských a humanitných vied vo všeobecnosti. Príkladom záujmu o problematiku etnicity v slovenskej etnológii môžu byṫ práce etnológa Jána Botíka, ktorý je jedným z popredných odborníkov na problematiku Slovákov žijúcich v zahraničí a etnických minorít žijúcich na Slovensku, ako aj odborníkom v oblasti teórií etnicity (Botík, 2007, 2011, 2016). Slovenskí etnológovia a antropológovia sa však zaoberali nielen životom a históriou etnických minorít na území Slovenska, ale aj fungovaním psychologických a kognitívnych mechanizmov pri uvažovaní l'udí o etnických skupinách (Kanovský, 2004, 2007, 2009). Štúdium etnicity na Slovensku predstavuje dynamicky sa rozvíjajúcu oblast' výskumu. Rovnako aj výskum minorít, migrácie a politických hnutí, ktoré súvisia s otázkou morálnych naratívov a etnicity, patrí k centrálnym oblastiam záujmu nielen etnológie a sociokultúrnej antropológie. Aj v slovenskom prostredí je im venovaná pozornost’ zo strany etnológov (napr. Bučičová, Tužinská, 2016; Hlinčíková, Mesežnikov, 2016; Mittelmannová, Vol’anská, Tužinská, 2009; Tužinská, 2010, 2020; Tužinská, Volanská, 2016). 
S otázkami etnicity sa spája aj problematika výskumu rasy, rasových klasifikácií v sociálnych a humanitných vedách. Jedným s najvýznamnejších bádatelov zaoberajúcich sa rasou a rasovými klasifikáciami je filozof Milan Hrabovský (Hrabovský, 2011, 2018). Vo svojich publikáciách Hrabovský syntetizuje relevantné informácie z mnohých disciplín (antropológia, biológia, genetika, história, filozofia, kultúrna a sociálna antropológia, sociológia atd'.), ktoré predkladá v jasnej a zrozumitel'nej forme. Hrabovský venuje pozornost’ predovšetkým pojmu rasa a rasovým klasifikáciám v širokých historických, teoretických a metodologických kontextoch. Okrem toho tiež upozorňuje na nedostatok literatúry v slovenskom kontexte, detailne sa venujúcej výhradne problematike rasy (Hrabovský, 2018: 4). Aj ked’ otázka rasy a rasových klasifikácií nie je v popredí záujmu, na Slovensku vzniklo viacero prác skúmajúc problematiku rasizmu a extrémizmu aj v kontexte etnických a národnostných menšín (napríklad Vašečka, 2002; Milo, 2005; Nižňanský, Hrabovský, 2013; Mesežnikov, Gyarfášová, 2016).

Politické skupiny a myšlienkové prúdy označované ako pravicovo a nacionalisticky orientované získavajú nielen v Európe čoraz väčšiu podporu. Naznačujú to napríklad výsledky parlamentných volieb, či volieb do orgánov samosprávnych krajov za posledných desat’ rokov, a to nielen na Slovensku. $V$ tomto kontexte je však potrebné poukázat’ aj na výsledky volieb do vyšších územných celkov na Slovensku, ktoré sa konali 4. 11. 2017. Tie ukázali, že podpora týchto strán má na Slovensku v niektorých okresoch aj klesajúcu tendenciu. Avšak negatívne postoje voči rozličným minoritám a imigrantom nezastávajú len voliči a sympatizanti spomínaných politických zoskupení. Čoraz častejšie sa s nimi stretávame naprieč rozličnými vekovými, profesijnými, náboženskými a d’alšími skupinami.

Všetky tieto aspekty skúmania etnicity ukazujú, že rasové a etnické klasifikácie priamo súvisia s morálnym uvažovaním. $V$ politickom a historickom kontexte sú súčastou kultúrnych predstáv o národoch v zmysle seba-identifikácie, ale aj vymedzenia vlastností „iných“ - či už národov, alebo národnostných minorít. K diskusii o morálnych naratívoch $\checkmark$ kontexte dejín etnických skupín, etnických stereotypov, predsudkov a migrácii boli pozvaní erudovaní odborníci - politológ Juraj Marušiak spolu s etnologičkou Sanjou Zlatanović, etnologička Helena Tužinská a etnológ Alexander Mušinka. Príspevky jednotlivých autorov sú vol'ne štruktúrované, tematicky je však diskusia rámcovaná nasledujúcimi všeobecnými otázkami, zodpovedanými z konkrétnej teoretickej a metodologickej perspektívy jednotlivých bádatelov:

1. Akú úlohu zohrávajú mocenské vztahy a kultúrne normy pri reprezentovaní dejín danej národnostnej menšiny v oficiálnom a verejnom diskurze (učebnice, politické vyjadrenia, masmédiá atd'.) a v diskurze lokálnom (obec, rodina, priatelia)? Na čo sa pri tomto reprezentovaní kladie dôraz a na čo sa zabúda?

2. Aké línie výskumu sú perspektívne pri vyplňovaní „bielych miest“ $v$ dejinách danej etnickej minority a čo považujete za nekorektný, prípadne zavádzajúci postup pri výskume?

3. Ako využívate historické naratívy rôznych druhov vo svojom výskume danej etnickej minority? 
Pozvanie do diskusie prijal Juraj Marušiak z Ústavu politických vied Slovenskej akadémie vied Sanja Zlatanović z Inštitútu etnografie SASA v Belehrade. Odborný záujem Marušiaka sa orientuje na politické systémy $v$ strednej a východnej Európe, regionálnu spoluprácu v strednej a východnej Európe, ako aj na najnovšie dejiny Slovenska (po roku 1945). Sanja Zlatanović upriamuje pozornost' na problematiku migrácie, etnicity a metodológie etnológie a antropológie. Spoločný príspevok autorov prináša historický, politologický a etnologický pohlad na problematiku Slovákov žijúcich v oblasti, ktorá je v slovenskej historiografii a literatúre označovaná ako Dolná zem. Marušiak a Zlatanović upriamujú pozornost' na vytváranie obrazu o vojvodinských Slovákoch na Slovensku a v Srbsku.

Do diskusie o dôležitých spoločenských a vedeckých otázkach prináša etnologický pohlad aj Alexander Mušinka pôsobiaci v Ústave rómskych štúdií na Prešovskej univerzite $\checkmark$ Prešove. Je autorom druhého diskusného príspevku. Mušinka, ktorý sa dlhodobo venuje výskumu rómskej menšiny na Slovensku, vo svojom príspevku otvára mnohé otázky, významné pre odbornú vedeckú obec.

Autorkou posledného príspevku je Helena Tužinská pôsobiaca na Katedre etnológie a muzeológie Filozofickej fakulty Univerzity Komenského v Bratislave. Medzi jej odborné záujmy dlhodobo patria otázky migrácie, utečencov a etnicity. $V$ diskusnom príspevku sa zaoberá zmenou ako základnou premennou, ale aj rezistenciou voči zmene $v$ historických naratívoch. Čast autorkiných úvah sa týka problematiky identity, rasových a etnických stereotypov, ako aj otázky ich reprodukcie vo verejnom diskurze, napríklad prostredníctvom učebníc základných škôl.

Všetky tri uvedené diskusie ukazujú potenciál etnologickej a antropologickej perspektívy. Domnievam sa, že prostredníctvom híbkového etnografického výskumu je možné aspoň do istej miery objasnit', prečo jednotlivci a skupiny zastávajú určité názory a postoje voči migrácii a minoritám, preferujú pri vol'bách isté politické strany či z akých dôvodov sa vyhýbajú kontaktu s cudzincami. Antropológovia a etnológovia disponujú potenciálom porozumiet ludskému správaniu z perspektívy samotných aktérov a tak vysvetlit spomínané postoje.

Ked’že predmetom etnologického a antropologického výskumu sú l'udia a spletité vztahy, do ktorých vstupujú, je o to dôležitejšie o teoretických, metodologických a etických problémoch antropologického výskumu intenzívne diskutovat nielen medzi univerzitnými pedagógmi a vedeckými pracovníkmi. Diskusia je motorom vedeckého bádania. Práve preto je nedelitel'nou súčastou Etnologických rozpráv. Odhalenie a následné riešenie teoretických, metodologických a etických problémov spoločenskovedného výskumu je nevyhnutné nielen pre pokrok vedeckého bádania samotného, ale aj pre úspešnú aplikáciu poznatkov $v$ praxi. Jednou z úlohou vedeckého bádania je podla môjho názoru poskytovat' možné riešenia spoločenských problémov (napr. nárast extrémizmu, intolerancie, šírenie hanlivých etnických a rasových stereotypov atd'.)

\section{Referencie}

Botík, J. (2007). Etnická história Slovenska: k problematike etnicity, etnickej identity, multietnického Slovenska a zahraničných Slovákov. Bratislava: Lúč. 
Botík, J. (2011). Dolnozemskí Slováci: Tri storočia vystahovaleckých osudov, spôsobu života a identity Slovákov v Mad’arsku, Rumunsku, Srbsku a Bulharsku. Nadlak: Vydavatel'stvo Ivan Krasko.

Botík, J. (2016). Slováci vo Vojvodine. Premeny svojbytnosti enklávneho spoločenstva. Nový Sad: Ústav pre kultúru Slovákov vo Vojvodine.

Bučičová, A. a Tužinská, H. (2016). Slová a moc. Prípadová štúdia zo súdneho pojednávania. Etnologické rozpravy, 23(2), 80-94.

Hlinčíková, M. a Mesežnikov, G. (Eds.). (2016). Otvorená krajina alebo nedobytná pevnost? Slovensko, migranti a utečenci. Bratislava: Inštitút pre verejné otázky. https://www.ivo.sk/8004/sk/publikacie/otvorena-krajina-alebo-nedobytna-pevnost?slovensko-migranti-a-utecenci

Hrabovský, M. (2011). Rasová mytológia. Bratislava: Kalligram.

Hrabovský, M. (2018). Rasa: rasová klasifikácia l’udí. Bratislava: VEDA.

Kanovský, M. (2004). Etnická identita, kognitívny prístup a terénny výskum: Ako na to? Etnologické rozpravy, 11(2), 11-24.

Kanovský, M. (2007). Essentialism and folksociology: ethnicity again. Journal of Cognition and Culture, 7(3-4), 241-281.

Kanovský, M. (2009). Esencializmus a etnicita: sociálno-kognitívne vysvetlenie reprezentovania sociálnych skupín. Sociologický časopis, 45(2), 345-368.

Mesežnikov, G. a Gyarfášová, O. (2016). Súčasný pravicový extrémizmus a ultranacionalizmus na Slovensku. Stav, trendy, podpora. Bratislava: Inštitút pre verejné otázky - Nadácia Hannsa Seidela.

Milo, D. (2005). Rasistický extrémizmus v Slovenskej republike. Bratislava: Ludia proti rasizmu.

Mittelmanová, M., Vol’anská, L.., Tužinská, H. (Eds.). (2009). Vybrané práva cudzincov na území SR a kultúrna rozmanitost: Princíp nenavrátenie, zlúčenie rodiny a kultúrna citlivost'. Bratislava: Stimul. http://www.old.hrl.sk/sites/default/files/publications/prava_ cudzincov_a_kulturna_rozmanitost.pdf

Ňižňanský, E. a Hrabovský, M. (2013). Rasizmus, antisemitizmus, holocaust (anticiganizmus). Bratislava: Stimul.

Tužinská, H. (2010). Otázky opisu a prekladu. Využitie poznatkov antropológie a etnografie vo vedení a tImočení interview s cudzincami. Bratislava: Stimul.

Tužinská, H. (2020). Medzi riadkami. Etnografia tımočenia azylových súdnych pojednávaní. Bratislava: AKAmedia.

Tužinská, H. a Vol'anská, L.. (Eds.). (2016). IN_akosti slovenské. Z rozprávaní cudzincov. Bratislava: CVEK. Centrum pre výskum etnicity a kultúry. http://cvek.sk/wp-content/ uploads/2016/10/INAKOSTI-SLOVENSKE_SVK.pdf

Vašečka, M. (Eds.). (2002). Čačipen pal o Roma. Súhrnná správa o Rómoch na Slovensku. Bratislava: Inštitút pre verejné otázky. 